\title{
SUSTAINABILITY AND COMMON-POOL RESOURCES: ALTERNATIVES TO TRAGEDY
}

Stanley R. Carpenter, Institute of Technology

\begin{abstract}
The paradox that individually rational actions collectively can lead to irrational outcomes is exemplified in human appropriation of a class of goods known as "common-pool resources" ("CPR"): natural or humanly created resource systems which are large enough to make it costly to exclude potential beneficiaries. A ppropriations of common-pool resources for private use tend toward abusive practices that lead to the loss of the resource in question: the tragedy of the commons. Prescriptions for escape from tragedy have involved two institutions, each applied largely in isolation from the other: private markets (the "hidden hand") and government coercion (L eviathan). Y et examples exist of local institutions that have utilized mixtures of public and private practices and have survived for hundreds of years.
\end{abstract}

Two problems further exacerbate efforts to avoid the tragic nature of common- pool resource use. One, given the current level of knowledge, the role of the resource is not recognized for what it is. It is, thus, in a fundamental, epistemological sense invisible. Two, if the resource is recognized, it may not be considered scarce, thus placing it outside the scrutiny of economic theory. Both types of error are addressed by the emerging field of ecological economics.

This paper discusses common pool resources, locates the ambiguities that make their identification difficult, and argues that avoidance of a CPR loss is inadequately addressed by sharply separated market and state institutions. W hen the resource is recognized for what it is, a common-pool good, which is subject to overexploitation, it may be possible to identify creative combinations of public and private institutions that can combine to save that resource. Disparate examples of self-organized enterprises, public/private utilities, and "green" taxes, to name a few, provide empirical content for developing theories of self-organized collective action. 


\section{INTRODUCTION}

For human life to persist and flourish into the indefinite future, technological practices must utilize resources in sustainable ways. N ot only is such not the case at present, but programs that would lead to sustainable resource use are hampered by failures to appreciate the full range of resources that do figure in human survival. Economic theories which define what is to count as a resource can significantly distort the problem of measuring resource consumption in two crucial ways. First, the selective focus of economic theory can completely fail to recognize a resource where one exists. Second, economic categories can be too broad, lumping together resources that need to be distinguished, or in those cases where distinctions are made between types of resources, failing to draw the distinctions at the correct point. Both errors directly effect technological designs. Technologies that mistakenly treat certain resources as unlimited public goods or, even worse, fail to recognize specific natural processes as valuable resources, can contribute, by inadvertence, to the depletion and even destruction of those resources. A dditionally, technologies which lump together humanly created capital such as food processing plants or refineries, with natural capital, such as fish stocks or mineral deposits, can lead to the unsustainable appropriation of resources.

In this paper I discuss these two types of errors: failures of resource recognition and failures of resource discrimination, both in the context of a familiar problem in resource use, the problem of resources. I dentifying these errors can lead to a better description of the scope of the common-pool resource (CPR) problem. A second error can then be addressed, the contention that CPR problems lead inevitably to "the tragedy of the commons" (Hardin 1968). Based on empirical research-both case studies and game theoretic laboratory experiments with human subjects-the deterministic nature of CPR appropriation can be challenged (Ostrom et al. 1995). This will not, however, lead to a sanguine assurance that CPR problems can always be avoided, that escape from tragedy is always possible. Rather, the identification of specific cases, some having succeeded for hundreds of years, where communities of people have devised schemes for avoiding the destruction of a common-pool resource, may provide some insight into sustainable resource use. In the end, however, it will be claimed that sustainable solutions to CPR problems are likely to display a wide variety of hybrid combinations of market and public practices. 


\section{TERM INOLOGY}

A vocabulary has evolved for designating different types of resources (Ostrom 1995, 7). We will follow these stipulations throughout the discussion. "Exclusion" refers to the degree to which access to a resource can be restricted. "Subtractability" deals with whether or not one person's appropriation of a resource reduces the availability of that resource for others. These two properties of a resource, exclusion and subtractability, lead to the generation of a two by two typology of resources, as follows:

\section{Table 1}

\section{RESOURCE TYPOLOGY}

LOW SUBTRACTABILITY

HIGH SUBTRACTABILITY

DIFFICULT EXCLUSION:

PUBLIC GOODS

COMMON POOL RESOURCES (CPR)

EASY EXCLUSION:

TOLL OR CLUB GOODS

PRIVATE GOODS

Resources, access to which is easily controlled, are of two types, "private" goods and "toll" or "club" goods. A ccess to private goods are controlled by the familiar institutions of private property. A ccess to toll or club goods is limited by the levying of tolls or the existence of membership restrictions.

On the other hand, access to two other types of resources cannot easily be denied. These include public goods, sometimes called "free goods," such as air and water, or public information systems, such as emergency radio broadcasts or scenic vistas. Other resources from which access is not easily restricted are called CPRs. These include fish grounds, groundwater basins, public parks or commons, etc.

The boundary between public goods and CPRs is not fixed. This is due to 
the other property crosscutting the four types of goods introduced, the property of subtractability. Public goods are considered low in subtractability. One person's use will not appreciably limit use by another. If one person listens to the emergency broadcast program, another's use of it most likely is not diminished. A $C P R$, on the other hand, is by definition high in subtractability, one person's use limits another's. On common land, the grass eaten by the animals of herder $A$ is unavailable for the animals of herder B. The system sensitivity between public goods and CPRs exists because a grazing field that is very large, supporting very few herders and grazing animals, has almost no subtractability vis-à-vis each herder. The commons is effectively a public good. It is when the commons is appropriated by many herders and/or many animals that it becomes unequivocally a CPR. Difficulty of exclusion, combined with high subtractability, can lead to the CPR dilemma Hardin calls the "tragedy of the commons."

Toll goods or club goods are considered low in subtractability. One person's use of the club only slightly affects another club member's access. Private goods are highly subtractable, since by definition what someone privatizes is not there for others.

\section{FAILURE TO RECOGNIZE A RESOURCE: VALUING NATURE}

Public goods do not easily lend themselves to valuation according to standard economic theories. In fact, they run the risk of not appearing in economic assessments at all. A recent article in the journal $\mathrm{N}$ ature by a group of economists and ecologists attempts to assign monetary values to various services which are performed by earth's ecosystems but which are "not fully captured in commercial markets or adequately quantified in terms comparable with economic services and manufactured capital..." (Costanza et al. 1997, 253). A n overall conservative estimate of seventeen ecological system services and natural capital stocks puts their value at between $\$ 16$ and $\$ 54$ trillion per year. By comparison, the gross national product of all the goods and services produced by all nations during one year is $\$ 18$ trillion. Consider, for example, the services provided by pollinators for plant reproduction. How much are honeybees and other pollinators worth? Their services are estimated to amount to \$117 million per year. Table 2 summarizes the estimated contributions of each of the seventeen categories. 
PHIL \& TECH 3:4 Summer 1998

Carpenter, Common-Pool Resources/40

\section{ESTIMATED M ONETARY VALUE OF SELECTED GLOBAL ECOSY STEM SER VICES (Costanza et al.1997, 253)}

ECOSYSTEM SY STEM
GAS REGULATION
CLIMATE REGULATION
DISTURBANCE
REGULATION
WATER REGULATION
WATER SUPPLY
EROSION CONTROL
AND SEDIMENT RETENTION
SOIL FORMATION
FOOD PRODUCTION
NOLLINATION
WASTE TREATMENT
POLICAL CONTROL
BEY CLING

DESCRIPTION

\$billion/yr

Carbon dioxide/ oxygen balance, ozone

1,341

for ultraviolet protection

684

Greenhouse gas regulation

1,779

recovery

Provision of water for irrigation, mills or

1,115 transportation

1,692

Provision of water by watersheds, reservoirs

and aquifers

576

Prevention of soil loss by wind, runoff, etc.;

storage of silt in lakes and wetlands

W eathering of rock and accumulation of organic material

$\mathrm{N}$ itrogen fixation

17,075

Pollution control, detoxification

2,227

Pollinators for plant reproduction

Predator control of prey species

N urseries, habitat for migratory species

Production of fish, game, crops, nuts and fruits by hunting, fishing, gathering or subsistence farming 
PHIL \& TECH 3:4 Summer 1998

RAW MATERIALS

GENETIC RESOURCES

RECREATION

CULTURAL
Carpenter, Common-Pool Resources/41

Production of lumber, fuel or fodder

721

M edicines, resistance genes for crops,

79

ornamental plant species, pets

E cotourism, sports fishing, other outdoor

815 recreation

Esthetic, artistic, educational, spiritual and/or scientific

\section{FAILURES TO DISCRIMINATE BETWEEN TYPES OF RESOURCES}

F ailure to identify and evaluate these important contributors to human welfare becomes a doubly critical error when it is realized that such systems can themselves be harmed by anthropogenic activities. The impacts of human activities on these services has the effect of shifting them from the category of a public good, with low subtractability, to a CPR, which is highly subtractable. The seriousness of this change in status, however, is obscured when the original ecosystem service was economically invisible. Thus, not only did the transition to an additional CPR from a free good actually occur, it did not even appear on an economic balance sheet. One of the difficulties in addressing a CPR problem is the uncertainty in assessing the extent and rate of loss of the resource. To this must thus be added the uncertainty that the loss will be detected at all.

Compounding failures of resource recognition are failures of accurate resource discrimination. For example, consider the relationship between natural capital and man-made capital. M an-made capital consists of human technologies, factories, financial institutions and other social inventions that facilitate human appropriation of the resources of the globe. Natural capital, on the other hand, is the stock that produces the flow of renewable and nonrenewable resources of the globe that supply the inputs to the man-made systems of capital. Standard neoclassical economics, however, treats these two types of capital as highly substitutable. Daly characterizes this claim of intersubstitutability as an outmoded relic of a world where man-made capital was insignificantly small in scale compared with natural capital. N ow man-made capital has become so vast in scale 
that it is itself limited by the decreasing supply of natural capital. The relation between natural capital and man-made capital, he argues, must be seen as complementary. "[W ]hat good," Daly asks, "is a saw mill without a forest? a refinery without petroleum deposits? a fishing boat without populations of fish? Beyond some point in the accumulation of man-made capital it is clear that the limiting factor on production will be remaining natural capital. For example, the limiting factor determining the fish catch is the reproductive capacity of fish populations, not the number of fishing boats; for gasoline the limiting factor is petroleum deposits, not refinery capacity; and for many types of wood it is remaining forests, not saw mill capacity" (1992, 25-6). M ischaracterization of the relationship between natural and man-made capital thus obscures a clear recognition of the seriousness of declining natural resources.

Natural capital may be privately owned, as in the case of a forest, or a $C P R$, as is the case with most fishing grounds. Even privatization, however, is no guarantee against the destruction of the privately owned resource. When a private forest is treated as income rather than capital, the cruel economic fact is that if the forest regeneration rate is less than the going rate of money, it is economically rational to "cut and run," investing the proceeds at the favorable financial rate. Failure to regard the privately held forest ecosystem as natural capital-while not amounting to a destruction of a CPR - is a destruction of nature's services nevertheless (Clark 1977).

\section{COMMON-POOL RESOURCES AND THE "TRAGEDY OF THE COMMONS"}

"The tragedy of the commons constitutes perhaps the most powerful bias against sustainable development" (Clark 1991, 323). Designation of certain CPRs with the metaphor "tragedy" is in near universal parlance since Hardin coined it three decades ago (Hardin 1968). The phenomenon, minus the attention getting symbolism, was clearly identified fourteen years earlier in Gordon's article, "The Economic Theory of a Common-Property Resource: The Fishery" (Gordon 1954). M uch earlier A ristotle wrote "what is common to the greatest number has the least care bestowed upon it. Everyone thinks chiefly of his own, hardly at all of the common interest" (Politics 2.3). 
The tragedy of the commons has been called a social dilemma because strategies that are individually rational collectively can produce irrational results. Hardin cited an obscure pamphlet, written in 1833 by an amateur mathematician, William Forster L loyd, describing a group of herders using common land. L loyd showed how each herder would regard it as in his own best interest to maximize his individual gain by adding animals to the commons. While any losses that would occur would be borne by all of the herders, the gain would be his. Since other herders would reason similarly, the only outcome of the process would be the destruction of the commons itself. Hardin chose the term "tragedy" to capture what he mistakenly believed to be the remorseless, deterministic, and destructive nature of the process as a whole.

A dopting Hardin's metaphor, others have cited examples of the tragedy everywhere, from those of air and water pollution, the extinction of marine species, to $M$ afia activities, drug racketeering and international terrorism. Hundreds of articles have been written on the subject. Hardin's primary application of the phrase was to the problem of world population. He argued that the common-pool of good will among peoples of the world which tolerated and often actively encouraged the "freedom to breed" would inevitably create a threat to the survival of the human species (Hardin 1968, 1243).

Y early reports from organizations such as the W orldwatch Institute or the W orld Resources Institute, which document the decline in the earth's ecosystems, depletion of both non-renewable resources and regenerative capacities of renewable resources, reinforce a fatalistic pessimism. $Y$ et, it is possible to challenge the accepted characterization of common pool resource use. There are, for example, long-enduring, self-organized resource institutions, the youngest of which has functioned sustainably for more than one hundred years, the oldest more than one thousand years.

In Törbel, Switzerland and the villages of Hirano, Nagaike, and Y amanoka, Japan, hybrid systems of private and communally owned institutions have used mountain meadows and forest products for hundreds of years. In Spain, in the region of $\mathrm{V}$ alencia, and in the Philippine Islands there are examples of irrigation systems have been maintained for similar lengths of time $(0$ strom 1990). For the past 140 years the $M$ enominee Tribe has inhabited N ortheast W isconsin and M ichigan's U pper Peninsula. During that period it has practiced 
sustainable forestry, even as the forests outside the reservation were depleted. Today there is more standing saw timber volume ( 1.7 billion board feet) than there was in 1854 (estimated at 1.2 billion board feet). During this same period over 2.25 billion board feet have been harvested from the same acreage (M enominee F orest Homepage).

The variety of institutional arrangements that are embodied in both successful and unsuccessful instances of CPR use is staggering. While the study of institutions of collective action appears to be in the formative stages, significant strides have been made. On the basis of mathematical game theory, laboratory simulation games, as well as detailed field analyses of cases such as those mentioned above (Ostrom, 1995), the elements of a framework for analysis of CPRs may well emerge.

\section{THE TRAGEDY OF THE COMM ONS AND THE PRISONER'S DILEMMA GAME}

Hardin's description of herders on a common has been conceptualized as a well known dilemma in mathematical game theory known as the "Prisoner's Dilemma." The properties of the prisoner's dilemma simulate the "locked in," inexorable quality by which $\mathrm{H}$ ardin characterized the tragic exploitation of the commons resource. Specifically, the prisoner's dilemma is characterized as a two person, non-cooperative game with full information. This means that both players-prisoners in this case-have full knowledge of the payoff matrix that mathematically describes the game of which they are a part.

Briefly, two prisoners, $A \& B$, suspected of robbery are put into separate cells, with no opportunity to communicate, and are urged to confess. If both confess, they will each get a four year sentence; if both deny, based on circumstantial evidence, they will each get a two year sentence. If one confesses and the other denies, the confessor goes free, and the other gets a five year sentence. The payoff matrix of which each prisoner is aware is as follows:

Table 3

PAY OFF MATRIX-PRISONER'S DILEMMA 


\section{ACTION}

Prisoner A

Cooperate (don't
confess)

Cooperate (don't

confess)

D efect (confess)

Defect (confess)

Defect (confess)

Cooperate (don't

confess)

$\begin{array}{lrr}\text { Prisoner B } & \text { Prisoner A } & \text { Prisoner B } \\ \begin{array}{l}\text { Cooperate (don't } \\ \text { confess) }\end{array} & -2(\mathrm{R}) & -2(\mathrm{R}) \\ \begin{array}{l}\text { Defect (confess) } \\ \text { Cooperate (don't }\end{array} & -5(\mathrm{~S}) & 0(\mathrm{~T}) \\ \begin{array}{l}\text { confess) } \\ \text { onfess) }\end{array} & -4(\mathrm{P}) & \\ \end{array}$

$R=$ Reward for mutual cooperation

$S=$ Sucker's payoff

$T=$ Temptation to defect

$P=$ Punishment for mutual defection )

"In summary, the Prisoner's Dilemma model postulates a condition in which the rational action of each individual is not to cooperate, that is, to defect, yet, if both parties act rationally, each party's reward is less than it would have been if both acted irrationally and cooperated" (Felkins 1997, 5).

Translating this dilemma into a CPR game, namely, Hardin's pasture commons, we have a two herder grazing game in which the cooperative strategy is for each herder to have half of the total grazing animals. The commons has an upper limit, $L$, to the number of animals it can sustain. A ccordingly, the cooperate strategy is for each herder always to keep her number of animals to $L / 2$. The defect strategy is to exceed that number. If both cooperate, they each receive, say, 10 units of profit. If both defect, they destroy the commons and receive no profit. If one cooperates and the other defects, the defector gets the profit from additional animals minus the lowered productivity per animal of the commons. The cooperator, on the other hand, suffers the sucker's fate of lower productivity without the compensating profit of additional animals. 


\section{THE TRAGEDY OF THE COMMONS AND THE FREE RIDER PROBLEM}

Because both public goods and CPRs are low in the property of exclusion they are susceptible to a problem familiar to students of public policy, the "free rider problem." When it is difficult to exclude any one person from a perceived good there is always the temptation to "free ride," even though that public good may cost something to provide. $\mathrm{N}$ ational defense is often cited as a public good provided both to taxpayers and non-taxpayers alike, although the latter receive the benefit at no cost, they ride free. In the case of the commons, the abuser is free riding on the careful behavior of the conscientious herder. The free rider problem and the commons dilemma share the property that while individual self-interested rationality appears to support behavior common to the collective good, such behavior is only possible as long as that collective good exists. If all ride free there is nothing to ride on!

\section{PROPOSED ESCAPE ROUTES FROM TRAGEDY}

It is necessary to remind ourselves that formalized games such as the prisoner's dilemma and Hardin's commons examples are mathematical models mapped onto a real world problem: the dilemma of CPR use. The fact that it is possible to identify both instances of successful long term management of CPRs as well as cases of failure points to the hazard of confusing the model with the empirical situation. It can be argued that Hardin is guilty of such confusion in characterizing the tragedy of the commons dilemma as a situation with "no technical solution" (Hardin 1968, 1,243). He identifies tic-tac-toe as another game with the same "no-win" game theoretic property.

The non-technical escapes from tragedy that Hardin does identify constitute a single dichotomous pair: private and public social institutions. On the one hand, the endangered resource is saved by privatization; on the other, by limiting access to the resource through the exercise of coercive state power. Exclusive application of either privatization-the hidden hand approach-or state coercion-L eviathan-is problematic. 


\section{THE HIDDEN HAND: PRIVATIZATION}

"[T] he only way to avoid the tragedy of the commons in natural resources and wildlife is to end the common-property system by creating a system of private property rights" (Sinn 1984 cited by Ostrom 1990, 12). It is when the commons is privatized, divided into parcels, fenced off, the argument goes, that individual responsibility is created. No longer faced with the threat of loss of resource, each herder can now be in full control of the pasture. There will be no temptation to overgraze since the entire private enterprise would be threatened by such irrational action. While it is no doubt the case that privatization can, in some instances, induce responsible resource use, there are a number of reasons why privatization is no panacea to the CPR allocation problem.

The "No M arket" A rgument. In order for a market to exist in any particular resource, the resource must be identified as such. But as al ready discussed, major natural systems, such as the earth's hydrological or gas cycles, are not part of market systems in the same way that, for instance, land is. Some of nature's services are simply not recognized at all. Others that are acknowledged are regarded as free or public goods, but not scarce in the sense required for privatization.

The Difficulty of Privatization A rgument. While forest ecosystems, scenic areas, mineral and metal deposits, landfills, etc., can have recognizable boundaries, ocean fish, air pollutants, the jet stream, the hydrologic and gaseous atmospheric systems are non-stationery or fugitive. Groundwater basins or oil fields fall between these extremes. Thus, while elaborate systems of privatization have evolved for dealing with some of the resources necessary for human survival, none exist for many others. The fugitive nature of many of these renders them unlikely candidates for privatization.

The Equity A rgument. Even if privatization of CPRs were completely attainable, a fundamental ethical problem would remain. Whose property would these resources be? Given that currently the top five hundred corporations control twenty-five percent of the gross world product and do it while employing 0.01 percent of the world's population (Hawken 1993, 91-2), one can guess at the answer. Braithwaite asks us to imagine what would happen if Exxon were to win the bid on the A laskan National Wildlife R efuge with its oil reserves beneath a 
complex ecosystem. "By handing the Refuge to Exxon we simply exchange one principle, wildlife preservation, for another, oil extraction. The oil extraction will very likely be successful because that is what Exxon does" (Braithwaite 1994).

In what sense could such a process be considered fair? That the USA would be the beneficiary of the bidding game points to an additional resource issue. A $n$ issue of international justice is raised by the fact that CPRs are not homogeneously distributed across the globe. Beitz observes that J ohn Rawls develops an analogy between the distribution of natural talents among members of a society and the distribution of natural resources among nations of the earth. In both cases, Rawls assumes initial distributions to be morally arbitrary. Just as the right to develop one's own talents is considered by Rawls to be properly within one's own control, so too does he consider the development of natural resources by any given nation to be a matter to be decided by that nation alone. Beitz questions this analogy. Development of one's talents does not limit others from developing their talents as well. But development of resources by any given nation, in a world of scarcity, could indeed limit the development plans of other nations.

A ppropriation of resources by those nations blessed with resources, possibly critical resources, could very well leave others worse off. A ccordingly, parties to an international original position "would know that resources are unevenly distributed with respect to population, that adequate access to resources is a prerequisite for successful operation of (domestic) cooperative schemes, and that resources are scarce" (Beitz 1988, 34). The result of this awareness "behind the veil of ignorance" would yield consensus that resource redistribution principles should be developed which would enable each society to individually develop just institutions and economies capable of meeting its member's needs (C arpenter 1997). It is most unlikely that redistribution would occur with privatization, since the initial distribution of resources of a private market is irrelevant to its efficient functioning. Redistribution would impose an inefficient and thus unacceptable aberration.

The Future Discounting A rgument. As noted above, privatization, is no guarantee against the destruction of a privately owned resource. When a privately held resource is treated as income rather than capital, it can be economically rational to liquidate it and invest the proceeds at the favorable financial rate. If a 
privately held resource, say, a hardwood forest, can sustain a harvest rate of $2 \%$ or $3 \%$ annually, with normal rates of return on investment in the neighborhood of $10 \%$, the "optimal" strategy in straight economic terms may be simply to "cut and run," wiping out the resource and investing the proceeds elsewhere. A related complication in dealing with conservation of resources for use in the future is known as "risk discounting." If a given biological resource is available now but uncertain in the future, given the possibility of unknown biological insults, its immediate harvesting can be seen as the rational thing to do.

Clark points out that the weal thy typically use lower time discounting rates than the poor. Put another way, waiting until later to cash in a resource looks less desirable to the person concerned with survival today than it does to the person with money in the bank. Unfortunately, the same principle applies to persons and nations alike. "Tropical deforestation feeds the pulp mills of J apanese, European and A merican firms enhancing their wealth, but leads to ever increasing poverty and desperation in the A mazon, the Philippines and Thailand" (Clark 1991, 325). Particularly in situations which discount the future heavily, and in the face of unavoidable uncertainty as to what the future will bring, there are no guarantees that privatization will present an escape route from overexploitative resource use (Clark 1977; Daly \& Cobb 1989, 410).

The Social Capital A rgument. "A competitive market-the epitome of private institutions-is itself a public good" (Ostrom 1990, 15). A dvocates of privatization as a way to avoid overexploiting CPRs ignore the fact that the institution of private property is itself a good made possible by the common laws, traditions, and precedents that flow from the body politic itself. Protections and obligations of private property holdings are under constant renegotiation.

What it means to be a landowner-what color, sex, ethnic origin, etc., such a person must be-as well as what one can do with property-dispose of chemicals on it, provide a habitat for dangerous or diseased animals, for example-all are subject to continuously renegotiated concepts of private ownership. Rights to property, along with access to courts for redress of grievances against threats to those rights, amounts to a public good.

A rthur Okun observes that a social and political system of democratic rights is required both to meliorate the inequalities generated by an unfettered 
market, and to provide the civilized "level playing field" on which the games of the market take place. "There is a place for the market, and the market must be kept in its place," he observed in the Godkin lectures (Okun 1975, 119). Thus the social and political nexus of support for privatization amounts, itself, to a type of social capital, a common-pool of cultural and political value. A market not kept in its place can lead to what Hardin has dubbed the "D ouble C-D ouble P Game: Communized Costs; Privatized Profits" (Cited by Clark 1991, 322).

Beyond the usual abuse of CPRs represented by air, water and land pollution, organized crime, drug rackets and terrorism also trade on the common pool of public trust that exists in a civilized society. Clark cites a recently exposed racket in which PCBs (toxic chemicals) were mixed with regular gasoline, trucked to $C$ anada, and sold to unsuspecting motorists. The M afia were said to be implicated in this and similar waste "disposal" businesses (Clark 1991, 323).

Consider the case of the $1987 \mathrm{M}$ ontreal Protocol banning the use of CFCs, linked to the destruction of the upper atmospheric ozone layer. (One pound of R-12 CFC can destroy 70,000 pounds of ozone.) Ultimately signed by 140 nations, this example of international cooperation is often cited as proof that nations are capable of joint action addressing extreme environmental problems. $Y$ et, after the ban had been in effect for only three years, a black market had developed; $\$ 1.5$ billion worth of the chemical were smuggled back into this country. Huge profits have accrued to the international outlaws, and the costs are shared by all.

A less apparent example, however, involves suburban housing developers who can build large numbers of houses cheaply, leading to traffic congestion, overcrowded schools, drainage problems, all of which affect the neighbors in inconvenience and higher taxes. The profits go to the developers, the community bears the costs. "Slap suits," whereby the developers, with deep pockets, use threats of expensive court costs to tie up the neighborhoods fighting a planned expansion, amount to abuses of the court of common law, itself publicly supported for the enforcement of property rights.

In sum, privatization, while an important social invention, should not be promoted as a panacea for dealing with CPRs. Since the orderly functioning of systems of private property depend on the common pool of social capital: laws, 
traditions, organized forms of protection, it should not be surprising that escapes from the tragedy of the commons must involve additional types of collective action.

\section{COERCION: LEVIATHAN}

Recognizing the impossibility of privatizing all scarce resources, $\mathrm{H}$ ardin coined the phrase "mutual coercion, mutually agreed upon" to encapsulate the only al ternative that would avoid the tragedy of the commons. It was quickly noted by commentators on Hardin's article that his solution was pure Hobbes. Thomas Hobbes' $\mathrm{s}$ "state of nature" is the inevitable result of the persistent condition in which all humans find themselves, a scarcity of resources necessary for survival. Desirous of the same things, which are unfortunately in short supply, humans must pit themselves against one another in lives of struggle that are nasty, poor, short, brutish and solitary. "Hereby it is manifest that, during the time men live without a common power to keep them all in awe, they are in that condition which is called war; and such a war as is of every man against every man" (Hobbes 1958, 106). To create that common power, Hobbes reasons that humans are willing to engage each other in a contract game, ceding individual power to an all powerful sovereign or commonwealth. Hobbes likens this coercive power to a "great L eviathan."

A ccording to L ocke, the "zero sum game" of scarce resources, which Hobbes said necessitated L eviathan, could be avoided by reinterpreting the problem of scarcity. Locke defined the institution of property as requiring both natural resources and human labor. Even as each person appropriated from the global commons, "... there was still enough and as good left; and more than the yet unprovided could use" (O phuls 1977, 144). In other words, L ocke has formulated what $D$ aly characterizes as the root metaphor of "empty earth economics" (Daly 1992, 23-37). Scarcity is a local problem. There is always someplace else to go to obtain raw material to mix with human labor and give value to; there is always a somewhere to "throw things to" when the value from that resource has been extracted. L ocke's concept of property combined with A dam Smith's promotion of the unfettered market, both identifying human labor as the engine of progress and the creator of value, effectively enshrined the logic of the commons in A merican political institutions and mores. "Our problem is not so much that our institutions no longer work the way they should-they work 
only too well even now in permitting the continued ruthless exploitation of the environment-but the assumptions about the carrying capacity of the commons which supported these institutions are no long true" (Ophuls 1973, 222).

In terms of territory, there is no longer an unclaimed "somewhere else" to go. The situation is more Hobbesian than L ockean. A ttempts to arrive at rational resource allocations require "full earth economics." If anything, the situation is more extreme than Hobbes' own characterization. One can be certain that CPRs already identified herein as nature's services-hydrologic cycles and water purification, atmospheric gas regulation, photosynthesis, pollination-have only recently become better recognized, though inadequately valued, as scarce resources.

Today, while the term "sustainability" is ubiquitous, there is very little reference to "steady-state economies" or "stable-state societies." A quarter of a century ago, proposals to limit population growth by licensing of parenthood, or to restrict the extraction of virgin material resources by systems of depletion quotas encountered firestorms of criticism as being worse than anything $\mathrm{H}$ obbes had envisaged. But the absence of such ideas in today's political discourse does not suggest the root problems are any less severe. Ironically, the collapse of the centrally planned economies that were held under the Soviet thumb have moved the industrial economies of the world and the "wannabes" away from the norms of steady-state economies including frugality, stewardship, and sufficiency. The good life on earth is much more likely to be viewed as an endless round of consumption, described by Boulding as a "cowboy economy" than as living on a spaceship where production, consumption and disposal must be in balance (Boulding 1977, 121-32).

\section{BEY OND EITHER MARKETS OR STATE COERCION}

The dichotomy of private market and public coercion suggests a hard and fast division between markets and governments. Today this is a monumentally misleading distinction. By one recent estimate $\$ 500$ billion in government subsidies worldwide are shunted into private enterprises such as logging, mining, fishing, and motor car production (Roodman 1996). M any of these subsidies contribute to the degradation of the global commons. If more rational approaches to appropriation of CPRs are to occur, they no doubt will involve creative 
alternatives to these subsidies that retain the private enterprise/public regulation distinction. Hawken describes one possible approach. Suppose, continuing Hardin's pasture example, a pasture utility were set up which operated independent of the practices of the herders. A ssume that it would be managed to maximize incomes from grazing fees. Herders would pay to graze and the utility would attempt to maximize income to the constituencies of the utility. The utility would have the incentive to maximize return to these shareholders and would have every reason to see that the commons was not degraded. The arrangement would contain elements of both public and private involvement.

Through the creative efforts of L ovins over the past two decades some electric power utilities have been persuaded to adopted the "negawatt" concept. L ovins developed detailed utility calculations that demonstrated that utility companies-by providing customers with insulation for their walls and even exchanging old inefficient refrigerators with new high efficiency ones, instead of building another power plant-could meet demand and keep customers happy while providing utility shareholders with good returns. Hawken speculates that "[t]hese utilities are probably the first corporate bodies that have invented a means to increase profitability by not growing, a paradox made possible by the fact that electricity derived from conservation costs only one-fifth to one-tenth as much as electricity that comes out of a new power plant" (Hawken 1993, 192).

Hawken applies the utility concept to the threatened salmon industry of the Pacific N orthwest. "To support the utility there would be a fee on salmon landed on the Pacific Coast. Those revenues would go directly to the central Salmon U tility... whose sole purpose would be to increase the stock of salmon" (Hawken 1993, 193). Because the utility would be limited as a monopoly to a fixed profit (10 to 12 percent annually) it would have an incentive to invest heavily in restoration. This would be a positive feedback situation, increasing the CPR while keeping the investors happy.

In addition to new forms of public utilities, CPR problems should be addressed by tax policies which insure that revenues are generated by taxing "bads" rather than "goods" or "illth" rather than "wealth." Such is the main function of "green taxes." A nnual fees would include severance taxes on virgin resources as well as taxes on emissions, fuels, products, wastes, etc. The idea is not to generate more revenue-ideally the al ternatives would be revenue neutral 
vis-à-vis current revenues-but by a gradual process extending over several years, to shift taxes from income and payroll to pollution, environmental degradation, and nonrenewable energy consumption (Hawken 1993, 171). Such tax policy would provide positive reinforcement for practices such as low energy transportation, telecommuting while slowing CPR depletion.

Additionally, tax policies which discriminate between revenues generated from mitigation of prior commerce that is harmful to the environment and revenues stemming from prudent, sustainable enterprise will help to frame human technologies in more rational terms.

One type of epistemological error, cited at the beginning of this paper involves the failure to recognize that something is a resource at all. As a corrective, new indicators must gain common parlance analogous to GNP and GDP. We have discussed how the commingling of humanly created capital with natural capital leads directly to mistakenly treating natural capital as income and to unsustainable depletion of CPRs. Daly and Cobb propose an Index of Sustainable E conomic W elfare (ISEW) to replace GDP and apply it to the years 1950 to 1986. Included in the index are the factors of income distribution (conventionally considered a non-economic equity issue), net capital growth (which excludes human capital), resource depletion (they reject the intersubstitutability of resource loss and newly created alternatives), energy output ratio (the increase expense of energy exploration, extraction, processing as reserves decline), and environmental damage. Their conclusion: since the late 1970s economic welfare has been deteriorating. $M$ ajor contributing factors to the decline include growing income inequality, exhaustion of resources, and the failure to invest adequately to sustain the economy of the future (Daly \& Cobb 1989, 455).

Despite the creative proposals that might lead to rational CPR policies involving green taxes, carbon taxes, "nega-watts" or "nega-barrels," significant obstacles block progress. In the first place, the major corporations routinely resist change. In the US, the $N$ ational A ssociation of $M$ anufacturers is on record against all forms of eco-taxes or green fees. The forest product giant W eyerhauser opposes any taxes on virgin timber. Because the economic power of transnationals is so great, this resistance seem virtually insurmountable. In the second place, the worldwide push toward international free trade, stemming from industry 
influenced government policies, has the effect of stifling local initiatives toward responsible environmental action. In fact, local, state or national statutes can be overridden by nonelected, international commissions, the most obvious and important example being the World Trade Organization, called by one critic "... a global parliament composed of unelected bureaucrats with the power to amend its own charter without referral to national legislative bodies" (K orten 1995, 176-77). International free trade allows the major industrial countries to continue to externalize the negative costs of business by locating plants in developing countries with weak environmental laws thus fully realizing the principle "communized costs; privatized profits." Perhaps the true win/win nature of green taxes will eventually be grudgingly accepted by these giant enterprises, but that time has not yet come.

\section{CONCLUSION}

A ppropriations of CPRs for private use tend toward abusive practices that lead to the loss of the resource in question. While this rule of thumb holds in many cases, there are exceptions. Examples of local institutions that have utilized mixtures of public and private practices and have survived for hundreds of years exist and have been referred to herein. When the focus of interest is broadened to national and global scales, and when the resource is fugitive, successful examples are much harder to find.

Two problems further exacerbate efforts to avoid the tragic nature of CPR use. One, resources may not even be recognized for what they are. The levels of knowledge of science may be such that the role of the resource is not recognized; in a fundamental epistemological sense, the resource is invisible. Or, if the resource is recognized, it is considered to be in such abundance that it does not suffer from scarcity and thus does not appear in economic equations. Both types of error have been discussed.

When the resource is recognized for what it is, a common-pool good subject to overexploitation, it may be possible to identify creative combinations of public and private institutions that can combine to save that resource. A sampling of possible policy options have been identified above that aim to avoid the untenable extremes of privatization of resources or absolute state coercion. 
PHIL \& TECH 3:4 Summer 1998

Carpenter, Common-Pool Resources/56

\section{REFERENCES}

Beitz, C. 1988. International distributive justice. In Problems of international justice, edited by S. L uper-Foy. Boulder: Westview Press.

Boulding, Kenneth E. 1977. Commons and community: The idea of a public. In M anaging the Common, edited by Garrett Hardin and J ohn Baden. San Francisco: W.H. Freeman and Company.

Braithwaite, T annis. 1994. The sins of our systems: Private and public failure to save our commons, http://communicopia.bc.ca/library/

Carpenter, Stanley. 1997. Ethics and sustainability. In V ol.4 of International Encyclopedia of A pplied Ethics. San Diego: A cademic Press, Inc.

Clark, Colin. 1977. The economics of overexploitation. In M anaging the Commons, edited by Garrett H ardin and J ohn Baden, 82-95. San Francisco: W. H. Freeman and Company. 1991. Economic biases against sustainable development. In Ecological economics: The science and management of sustainability, edited by Robert Costanza. N ew Y ork: Columbia University Press.

Costanza, Robert et al. 1997. The value of the world's ecosystem services and natural capital. Nature 387 (M ay):253-60.

Daly, Herman E. 1992. From empty-world economics to full-world economics: Recognizing an historical turning point in economic development. In Population, technology, and lifestyle: The transition to sustainability, edited by R. Goodland, H.E. Daly, and Salah EI Serafy. Washington, DC: Island Press.

Daly, Herman E. A nd J ohn B. Cobb, Jr. 1989. For the common good: Redirecting the economy toward community, the environment, and a sustainable future. Boston: Beacon Press.

Felkins, Leon. 1997. A rational justification for ethical behavior. http://www.ios.com/ leonf/ common/moral3. html.

Gordon, H. Scott. 1954. The economic theory of a common-property resource: The fishery. The Journal of Political Economy 62 (A pril): 124.

Hardin, Garrett. 1968. The tragedy of the commons. Science 162: 1243-8.

Hawken, Paul. 1993. The ecology of commerce: A declaration of sustainability. New Y ork: Harper Business.

Hobbes, Thomas. 1958. Leviathan: Parts one and two. Indianapolis, IN : Bobbs-M errill Co., Inc.

Korten, David C. 1995. When corporations rule the world. W est Hartford, CT: Kumarian Press, Inc.

M enominee F orest Homepage. 1997. http://www. menominee. com/mte/FOREH OM E. HTM L: [cited 29 A ugust 1997].

Okun, Arthur. 1975. Equality and efficiency: The big tradeoff. Washington, D.C.: The Brookings Institution.

Ophuls, William. 1973. Leviathan or oblivion? In Toward a steady-state economy, edited by Herman E. Daly. San Francisco: W.H. Freeman and Company. 1977. Ecology and the politics of scarcity. San Francisco: W.H.F reeman and Company.

Ostrom, Elinor. 1990. Governing the commons: The evolution of institutions for collective action. Cambridge: Cambridge U niversity Press.

Ostrom, Elinor et al. 1995. A nalyzing long-enduring, self-organized, and self-governing CPRs. In 
PHIL \& TECH 3:4 Summer 1998

Rules, games, \& common-pool resources. Ann Arbor: U niversity of M ichigan Press.

Roodman, David M. 1996. Paying the piper: Subsidies, politics, and the environment. Worldwatch Paper 133, W ashington, DC: W orldwatch Institute.

1997. Getting the signals straight: Tax reform to protect the environment and the economy. W orldwatch Paper 134. Washington, DC: W orldwatch Institute.

Sinn, H.W. 1984. Common property resources, storage facilities and ownership structures: A Cournot model of the oil market. Economica 51: 235-52. 